\title{
Mapping of candidate tumor suppressor genes on chromosome 12 in adenoid cystic carcinoma
}

\author{
Sue Rutherford ${ }^{1}$, Garret M Hampton ${ }^{2}$, Henry F Frierson $\mathrm{Jr}^{1}$ and Christopher A Moskaluk ${ }^{1}$ \\ ${ }^{1}$ Department of Pathology, University of Virginia Health System, Charlottesville, VA, USA and ${ }^{2}$ Genomics \\ Institute of the Novartis Research Foundation, San Diego, CA, USA
}

\begin{abstract}
Adenoid cystic carcinoma (ACC) is a common malignancy of salivary glands, for which the underlying genetic mechanisms of tumorigenesis are poorly understood. Prior studies in ACC have identified deletions in chromosome 12. To further characterize these changes, we performed an extensive LOH analysis in 58 ACC using a panel of 28 microsatellite markers. Results show $66 \%$ overall genetic loss. Three markers (D12S1713, $D 12 S 2196, D 12 S 398)$ are contiguous and define a $6.84 \mathrm{Mb}$ region of deletion at 12q13.11-q13.13. Two other markers (D12S2078, D12S1628) are also contiguous and define a 4.5 Mb region of deletion at 12q24.32-q24.33. The three remaining markers, D12S1056 at 12q14.1, D12S1051 at 12q23.1 and D12S1636 at 12q23.3 define smaller regions of deletion. An analysis of microarray gene expression profiling data available for ACC shows several genes with significant transcriptional downregulation that map to these areas of genetic deletion. This combined genetic and genomic analysis provides several candidate genes to test for functional tumor suppressor activity in ACC.
\end{abstract}

Laboratory Investigation (2005) 85, 1076-1085. doi:10.1038/labinvest.3700314; published online 18 July 2005

Keywords: adenoid cystic carcinoma; genetic deletion; loss of heterozygosity; tumor suppressor gene; microarray

Adenoid cystic carcinoma (ACC) is one of the most common malignant tumors of salivary glands, but little is known of the molecular changes involved in its pathogenesis. Cytogenetic, comparative genomic hybridization (CGH) and loss of heterozygosity $(\mathrm{LOH})$ analyses have shown that one of the most frequent genetic changes (deletions and rearrangements) occur on chromosome 6, with other chromosomal changes (such as on 9 and 17) reported less commonly. ${ }^{1-12}$ In a previous CGH analysis of 24 tumors, we found a previously unreported loss at the $12 q 12-q 13$ region. ${ }^{12}$ We confirmed our CGH findings by conducting a limited $\mathrm{LOH}$ analysis in 29 ACC samples using three chromosome 12 microsatellite markers (D12S391, D12S1301 and D12S1064) to show overall loss on chromosome 12 was similar to that found by CGH analysis. Additional support for involvement of 12q12-q13 in ACC came from a study showing karyotypic changes affecting 12q12-q13 in three cases of tumor. ${ }^{13}$

Correspondence: Dr CA Moskaluk, MD, PhD, Department of Pathology, University of Virginia Health System, PO Box 800214, Charlottesville, VA 22908-0708, USA.

E-mail: cam5p@virginia.edu

Received 2 February 2005; revised and accepted 24 May 2005; published online 18 July 2005
To further refine the map of chromosome 12 deletion in ACC, in this study we allelotyped 58 ACC and matched normal samples in a more extensive LOH analysis using a panel of 28 microsatellite markers. The results of the deletion mapping are correlated with microarray gene expression profiling data from primary samples of ACC. Areas of frequent genetic deletion in tumors are associated with inactivation of tumor suppressor genes, that may also be inactivated by transcriptional silencing. This combination of genetic deletion mapping and positional transcriptional mapping has identified candidate tumor suppressor genes in ACC.

\section{Materials and methods}

Tumor and Normal Samples for Deletion Analysis

The Institutional Review Board of the University of Virginia Health System provided approval for this study. In addition to the 29 ACC samples used in the previous CGH study, ${ }^{12}$ we tested a further 29 formalin-fixed, paraffin-embedded cases of ACC collected from the files of the Division of Surgical Pathology at the University of Virginia Health System, which included cases resected at the 
University of Virginia as well as material representing cases sent in consultation from other institutions. As shown in Table 1, tumors were graded as lesions with no solid component (grade I), $<30 \%$ solid areas (grade II) and $>30 \%$ solid component (grade III). ${ }^{14}$ Table 1 also shows the pathologic staging, based on the AJCC Cancer Staging Manual criteria (fifth edition). Patient follow-up data from the McIntire Tumor Registry at the University of Virginia Health System was available for 32 patients. All 58 ACC were microdissected to $75-95 \%$ purity and DNA was extracted from tissues as previously published. ${ }^{15}$

\section{Cell Culture}

The ACC3 cell system was established from an ACC of the parotid gland of a 49-year-old man as previously described, ${ }^{16-18}$ and is the most widely distributed cell culture model of ACC. ACC3 cells were kindly provided by Dr Takashi Saku of Niigata University School of Dentistry, Japan and were cultured in RPMI-1640 medium (Life Technologies cat\# 10370-021) containing $15 \%(\mathrm{v} / \mathrm{v})$ fetal calf serum, $1 \%$ glutamine, $1 \%$ amphotericin $\mathrm{B}, 1 \%$ streptomycin and $1 \%$ penicillin and incubated in a humidified $5 \% \mathrm{CO}_{2} / 95 \%$ air atmosphere at $37^{\circ} \mathrm{C}$. This cell line has been shown to have a gene expression profile similar to that of primary ACC in microarray experiments, ${ }^{19}$ has basement membrane synthesis function similar to primary ACC $^{16,18,20,21}$ and when grown as a xenograft tumor in immunodeficient mice, have a histologic appearance consistent with a grade III ACC. ${ }^{16}$ DNA from confluent ACC3 cells was extracted similarly to the tissue samples, with the addition of phenol/chloroform extraction and ethanol precipitation.

\section{Microsatellite Loss of Heterozygosity (LOH) Assays}

MapPairs ${ }^{\mathrm{TM}}$ primers for the 28 microsatellite markers shown in Figure 1 were obtained from Research Genetics (Huntsville, AL, USA). Radiolabeled PCR amplification, gel electrophoresis, autoradiography of microsatellite markers and $\mathrm{LOH}$ determination were performed as previously described. ${ }^{15} \mathrm{~A}$ tumor was determined to have undergone $\mathrm{LOH}$, be informative or noninformative at a particular locus using the same criteria as that described previously. ${ }^{12}$ All losses were confirmed in an independent PCR assay.

Calculations were performed in a spreadsheet computer program (Excel 98, Microsoft Co.) to determine LOH rate and averages for marker heterozygosity, frequency of allelic loss (FAL) index, $\mathrm{LOH}$ size and number of LOH hotspots. ${ }^{22}$ For this study, the FAL index on chromosome 12 was determined according to criteria of Vogelstein et $\mathrm{al}^{23}$ that defined the extent of allele loss as the ratio of the number of $\mathrm{LOH}$ events in a sample to the total informative (heterozygous) markers in the corresponding normal DNA. Similarly, the number of informative markers in normal DNA determined marker heterozygosity. The number of contiguous markers showing LOH (including noninformative markers flanking LOH regions) determined the size of allelic loss. ${ }^{22}$ The rate of allelic loss was determined from the amount of $\mathrm{LOH}$ per informative case. The $\mathrm{LOH}$ rate was determined by dividing the number of contiguous markers showing LOH (including noninformative markers flanking $\mathrm{LOH}$ regions) by the heterozygosity of the various markers displayed in the ACC samples. $\mathrm{LOH}$ rates $<30 \%$ are mostly due to random or semirandom genetic changes and those $>35 \%$ likely result from nonrandom genetic deletions. ${ }^{22}$

\section{Microsatellite Homozygosity Mapping of Deletion (HOMOD) Analysis}

DNA extracted from the ACC3 cell line was analyzed with the same panel of 28 microsatellite markers shown in Figure 1 using a similar radiolabeled PCR amplification and gel electrophoresis assay to the LOH analysis. DNA samples extracted from non-neoplastic tissue samples were used as positive controls. Autoradiography of microsatellite markers and determination of homozygosity was performed similar to the $\mathrm{LOH}$ assay. All assays were independently scored by at least two individuals (SR and CAM). We determined homozygosity of microsatellite markers when heterozygosity was not identified in the DNA of the ACC3 cell line. Homozygosity of five consecutive markers with a heterozygosity of at least 0.75 was statistically considered to show a region of chromosomal deletion. ${ }^{24}$ Deletions in the cell line were deduced on the basis of marker heterozygosity values that any set of adjacent homozygous genotypes would be observed in normal control DNAs.

\section{Correlation with Gene Expression Profiles}

Data are available from gene expression profiling of 15 primary ACC and five normal salivary glands on U95a Affymetrix GeneChips ${ }^{\mathrm{TM}}$ as previously described. ${ }^{19}$ Using the cytogenetic locations of $12 q 12,12 q 13$ and $12 q 24$, the U95a probe sets that corresponded to genes in these areas were obtained from the UCSC Genome Browser Query function of the NETAFFX ${ }^{\mathrm{TM}}$ Analysis Center. ${ }^{25}$ For the $12 q 12-$ $12 q 13$ locus, there was data for 209 probe sets, for the 12q24 locus there were 139 probe sets. The data were filtered to remove probe sets in which the average relative fluorescence units (after scaling) was $\leq 0$ for the normal salivary gland samples, and to remove samples in which the fold change in average fluorescence intensity between normal and cancer tissues was $<2$. 
Table 1 Clinical and pathologic parameters of ACC cases correlated to $12 \mathrm{q} \mathrm{LOH}$

\begin{tabular}{|c|c|c|c|c|c|c|c|c|c|c|c|c|}
\hline Code & Gender & $A g e^{\mathrm{a}}$ & Race & Stage $^{\mathrm{b}}$ & Grade $^{\mathrm{c}}$ & $S . G^{\mathrm{d}}$ & $\begin{array}{c}\text { Any } 12 q \\
\text { LOH }\end{array}$ & $\begin{array}{c}12 q 13.11- \\
q 13.13 \mathrm{LOH}\end{array}$ & $\begin{array}{c}12 q 14.1 \\
L O H\end{array}$ & $\begin{array}{c}12 q 23.1 \\
L O H\end{array}$ & $\begin{array}{c}12 q 23.3 \\
L O H\end{array}$ & $\begin{array}{c}12 q 24.32- \\
q 24.33 \mathrm{LOH}\end{array}$ \\
\hline 01 & $\mathrm{~F}$ & 49 & W & I & 1 & Minor & $\mathrm{Y}$ & $\mathrm{N}$ & $\mathrm{N}$ & $\mathrm{N}$ & $\mathrm{N}$ & Y \\
\hline 02 & M & 68 & W & I & 1 & Major & $\mathrm{N}$ & $\mathrm{N}$ & $\mathrm{N}$ & $\mathrm{N}$ & $\mathrm{N}$ & $\mathrm{N}$ \\
\hline 03 & $\mathrm{~F}$ & 54 & W & I & 1 & Minor & $\mathrm{Y}$ & $\mathrm{N}$ & $\mathrm{N}$ & $\mathrm{N}$ & $\mathrm{N}$ & Y \\
\hline 04 & M & 70 & W & I & 1 & Minor & $\mathrm{N}$ & $\mathrm{N}$ & $\mathrm{N}$ & $\mathrm{N}$ & $\mathrm{N}$ & $\mathrm{N}$ \\
\hline 05 & $\mathrm{~F}$ & 54 & $\mathrm{~W}$ & II & 1 & Major & $\mathrm{Y}$ & $\mathrm{Y}$ & $\mathrm{Y}$ & $\mathrm{N}$ & $\mathrm{N}$ & $\mathrm{N}$ \\
\hline 06 & M & 53 & W & III & 1 & Minor & $\mathrm{Y}$ & $\mathrm{N}$ & $\mathrm{N}$ & $\mathrm{Y}$ & Y & Y \\
\hline 07 & M & 65 & W & IV & 1 & Major & $\mathrm{N}$ & $\mathrm{N}$ & $\mathrm{N}$ & $\mathrm{N}$ & $\mathrm{N}$ & $\mathrm{N}$ \\
\hline 08 & M & 64 & W & IV & 1 & Minor & $\mathrm{Y}$ & $\mathrm{Y}$ & $\mathrm{Y}$ & $\mathrm{N}$ & $\mathrm{N}$ & $\mathrm{Y}$ \\
\hline 09 & $\mathrm{~F}$ & 58 & W & IV & 1 & Major & Y & $\mathrm{N}$ & $\mathrm{Y}$ & $\mathrm{N}$ & $\mathrm{N}$ & $\mathrm{N}$ \\
\hline 10 & $\mathrm{~F}$ & 57 & W & I & 2 & Minor & $\mathrm{Y}$ & $\mathrm{N}$ & $\mathrm{N}$ & $\mathrm{Y}$ & $\mathrm{Y}$ & $\mathrm{N}$ \\
\hline 11 & $\mathrm{~F}$ & 50 & W & I & 2 & Major & $\mathrm{Y}$ & Y & $\mathrm{Y}$ & Y & $\mathrm{Y}$ & $\mathrm{N}$ \\
\hline 12 & $\mathrm{~F}$ & 36 & W & I & 2 & Minor & $\mathrm{N}$ & $\mathrm{N}$ & $\mathrm{N}$ & $\mathrm{N}$ & $\mathrm{N}$ & $\mathrm{N}$ \\
\hline 13 & $\mathrm{U}$ & $\mathrm{U}$ & $\mathrm{U}$ & II & 2 & Minor & $\mathrm{N}$ & $\mathrm{N}$ & $\mathrm{N}$ & $\mathrm{N}$ & $\mathrm{N}$ & $\mathrm{N}$ \\
\hline 14 & M & 64 & W & IV & 2 & Major & $\mathrm{N}$ & $\mathrm{N}$ & $\mathrm{N}$ & $\mathrm{N}$ & $\mathrm{N}$ & $\mathrm{N}$ \\
\hline 15 & $\mathrm{~F}$ & 33 & W & IV & 2 & Major & $\mathrm{N}$ & $\mathrm{N}$ & $\mathrm{N}$ & $\mathrm{N}$ & $\mathrm{N}$ & $\mathrm{N}$ \\
\hline 16 & $\mathrm{~F}$ & 48 & W & IV & 2 & Minor & $\mathrm{Y}$ & Y & $\mathrm{N}$ & $\mathrm{N}$ & $\mathrm{N}$ & $\mathrm{N}$ \\
\hline 17 & $\mathrm{~F}$ & 43 & W & III & 1 & Minor & $\mathrm{Y}$ & $\mathrm{N}$ & $\mathrm{Y}$ & $\mathrm{N}$ & $\mathrm{N}$ & $\mathrm{N}$ \\
\hline 18 & $\mathrm{~F}$ & 72 & W & $\mathrm{X}$ & 1 & Minor & $\mathrm{Y}$ & $\mathrm{Y}$ & $\mathrm{N}$ & $\mathrm{N}$ & $\mathrm{N}$ & $\mathrm{N}$ \\
\hline 19 & M & 69 & W & II & 3 & Minor & $\mathrm{Y}$ & $\mathrm{Y}$ & $\mathrm{Y}$ & $\mathrm{N}$ & $\mathrm{N}$ & $\mathrm{N}$ \\
\hline 20 & $\mathrm{~F}$ & 57 & W & IV & 3 & Major & $\mathrm{N}$ & $\mathrm{N}$ & $\mathrm{N}$ & $\mathrm{N}$ & $\mathrm{N}$ & $\mathrm{N}$ \\
\hline 21 & $\mathrm{U}$ & $\mathrm{U}$ & $\mathrm{U}$ & IV & 3 & Minor & $\mathrm{N}$ & $\mathrm{N}$ & $\mathrm{N}$ & $\mathrm{N}$ & $\mathrm{N}$ & $\mathrm{N}$ \\
\hline 22 & M & 50 & W & IV & 3 & Minor & $\mathrm{Y}$ & $\mathrm{Y}$ & $\mathrm{Y}$ & $\mathrm{N}$ & $\mathrm{N}$ & $\mathrm{N}$ \\
\hline 23 & $\mathrm{~F}$ & 73 & B & III & 3 & Major & $\mathrm{Y}$ & $\mathrm{Y}$ & $\mathrm{N}$ & $\mathrm{N}$ & $\mathrm{N}$ & $\mathrm{N}$ \\
\hline 24 & $\mathrm{~F}$ & 63 & W & III & 3 & Major & $\mathrm{Y}$ & $\mathrm{Y}$ & $\mathrm{Y}$ & $\mathrm{Y}$ & $\mathrm{Y}$ & $\mathrm{Y}$ \\
\hline 25 & $\mathrm{~F}$ & 49 & W & $\mathrm{X}$ & 2 & Major & $\mathrm{Y}$ & $\mathrm{Y}$ & $\mathrm{N}$ & $\mathrm{N}$ & $\mathrm{N}$ & Y \\
\hline 26 & M & 32 & W & I & 3 & Minor & $\mathrm{N}$ & $\mathrm{N}$ & $\mathrm{N}$ & $\mathrm{N}$ & $\mathrm{N}$ & $\mathrm{N}$ \\
\hline 27 & M & 55 & $\mathrm{~W}$ & $\mathrm{X}$ & 1 & Minor & $\mathrm{Y}$ & $\mathrm{N}$ & $\mathrm{N}$ & $\mathrm{N}$ & $\mathrm{N}$ & Y \\
\hline 28 & M & 43 & W & IV & 3 & Minor & $\mathrm{N}$ & $\mathrm{N}$ & $\mathrm{N}$ & $\mathrm{N}$ & $\mathrm{N}$ & $\mathrm{N}$ \\
\hline 29 & $\mathrm{~F}$ & 51 & W & IV & 3 & Minor & $\mathrm{N}$ & $\mathrm{N}$ & $\mathrm{N}$ & $\mathrm{N}$ & $\mathrm{N}$ & $\mathrm{N}$ \\
\hline 30 & $\mathrm{~F}$ & 32 & $\mathrm{U}$ & X & 1 & Minor & $\mathrm{Y}$ & $\mathrm{N}$ & $\mathrm{N}$ & $\mathrm{N}$ & $\mathrm{N}$ & Y \\
\hline 31 & $\mathrm{U}$ & $\mathrm{U}$ & $\mathrm{U}$ & $X$ & 3 & Minor & $\mathrm{N}$ & $\mathrm{N}$ & $\mathrm{N}$ & $\mathrm{N}$ & $\mathrm{N}$ & $\mathrm{N}$ \\
\hline 32 & $\mathrm{~F}$ & 52 & $\mathrm{U}$ & $\mathrm{X}$ & 1 & Minor & $\mathrm{Y}$ & $\mathrm{Y}$ & $\mathrm{Y}$ & $\mathrm{Y}$ & $\mathrm{Y}$ & $\mathrm{N}$ \\
\hline 33 & $\mathrm{~F}$ & 46 & $\mathrm{U}$ & X & 1 & Minor & $\mathrm{N}$ & $\mathrm{N}$ & $\mathrm{N}$ & $\mathrm{N}$ & $\mathrm{N}$ & $\mathrm{N}$ \\
\hline 34 & $\mathrm{~F}$ & 44 & $\mathrm{U}$ & $\mathrm{X}$ & 3 & Major & $\mathrm{N}$ & $\mathrm{N}$ & $\mathrm{N}$ & $\mathrm{N}$ & $\mathrm{N}$ & $\mathrm{N}$ \\
\hline 35 & $\mathrm{~F}$ & 85 & $\mathrm{U}$ & $\mathrm{X}$ & 2 & Major & $\mathrm{Y}$ & $\mathrm{N}$ & $\mathrm{N}$ & $\mathrm{N}$ & $\mathrm{N}$ & Y \\
\hline 36 & $\mathrm{M}$ & 80 & $\mathrm{U}$ & $X$ & 1 & Minor & $\mathrm{Y}$ & $\mathrm{N}$ & $\mathrm{Y}$ & $\mathrm{N}$ & $\mathrm{N}$ & $\mathrm{N}$ \\
\hline 37 & $\mathrm{~F}$ & 51 & W & I & 1 & Minor & $\mathrm{Y}$ & $\mathrm{N}$ & $\mathrm{N}$ & $\mathrm{Y}$ & $\mathrm{N}$ & $\mathrm{N}$ \\
\hline 38 & $\mathrm{~F}$ & 76 & W & III & 2 & Minor & $\mathrm{Y}$ & $\mathrm{N}$ & $\mathrm{N}$ & $\mathrm{Y}$ & $\mathrm{Y}$ & Y \\
\hline 39 & $\mathrm{U}$ & $\mathrm{U}$ & $\mathrm{U}$ & $\mathrm{X}$ & 1 & Minor & $\mathrm{N}$ & $\mathrm{N}$ & $\mathrm{N}$ & $\mathrm{N}$ & $\mathrm{N}$ & $\mathrm{N}$ \\
\hline 40 & $\mathrm{U}$ & $\mathrm{U}$ & $\mathrm{U}$ & X & 1 & Major & $\mathrm{N}$ & $\mathrm{N}$ & $\mathrm{N}$ & $\mathrm{N}$ & $\mathrm{N}$ & $\mathrm{N}$ \\
\hline 41 & $\mathrm{M}$ & 40 & $\mathrm{U}$ & $\mathrm{X}$ & 1 & Major & $\mathrm{N}$ & $\mathrm{N}$ & $\mathrm{N}$ & $\mathrm{N}$ & $\mathrm{N}$ & $\mathrm{N}$ \\
\hline 42 & $\mathrm{~F}$ & 45 & B & IV & 3 & Minor & $\mathrm{N}$ & $\mathrm{N}$ & $\mathrm{N}$ & $\mathrm{N}$ & $\mathrm{N}$ & $\mathrm{N}$ \\
\hline 43 & $\mathrm{U}$ & $\mathrm{U}$ & $\mathrm{U}$ & $\mathrm{X}$ & 2 & Major & $\mathrm{N}$ & $\mathrm{N}$ & $\mathrm{N}$ & $\mathrm{N}$ & $\mathrm{N}$ & $\mathrm{N}$ \\
\hline 44 & $\mathrm{M}$ & 72 & W & IV & 2 & Minor & $\mathrm{N}$ & $\mathrm{N}$ & $\mathrm{N}$ & $\mathrm{N}$ & $\mathrm{N}$ & $\mathrm{N}$ \\
\hline 45 & $\mathrm{M}$ & 32 & $\mathrm{U}$ & $\mathrm{X}$ & 2 & Major & $\mathrm{Y}$ & $\mathrm{Y}$ & $\mathrm{N}$ & $\mathrm{Y}$ & $\mathrm{Y}$ & Y \\
\hline 46 & $\mathrm{~F}$ & 72 & $\mathrm{U}$ & $\mathrm{X}$ & 1 & Minor & $\mathrm{N}$ & $\mathrm{N}$ & $\mathrm{N}$ & $\mathrm{N}$ & $\mathrm{N}$ & $\mathrm{N}$ \\
\hline 47 & M & 71 & $\mathrm{U}$ & $\mathrm{X}$ & 1 & Minor & $\mathrm{Y}$ & $\mathrm{N}$ & $\mathrm{N}$ & $\mathrm{N}$ & $\mathrm{N}$ & $\mathrm{Y}$ \\
\hline 48 & $\mathrm{~F}$ & 46 & W & IV & 3 & Major & $\mathrm{Y}$ & $\mathrm{Y}$ & $\mathrm{Y}$ & Y & $\mathrm{Y}$ & $\mathrm{N}$ \\
\hline 49 & M & 50 & $\mathrm{U}$ & $\mathrm{X}$ & 1 & Major & $\mathrm{Y}$ & $\mathrm{N}$ & $\mathrm{N}$ & $\mathrm{Y}$ & $\mathrm{N}$ & $\mathrm{N}$ \\
\hline 50 & M & 62 & W & II & 2 & Minor & $\mathrm{Y}$ & Y & Y & Y & $\mathrm{Y}$ & $\mathrm{N}$ \\
\hline 51 & $\mathrm{U}$ & $\mathrm{U}$ & $\mathrm{U}$ & $\mathrm{X}$ & 1 & Major & $\mathrm{N}$ & $\mathrm{N}$ & $\mathrm{N}$ & $\mathrm{N}$ & $\mathrm{N}$ & $\mathrm{N}$ \\
\hline 52 & $\mathrm{~F}$ & 54 & $\mathrm{U}$ & $\mathrm{X}$ & 2 & Minor & $\mathrm{N}$ & $\mathrm{N}$ & $\mathrm{N}$ & $\mathrm{N}$ & $\mathrm{N}$ & $\mathrm{N}$ \\
\hline 53 & M & 26 & W & I & 1 & Major & $\mathrm{N}$ & $\mathrm{N}$ & $\mathrm{N}$ & $\mathrm{N}$ & $\mathrm{N}$ & $\mathrm{N}$ \\
\hline 54 & $\mathrm{~F}$ & 64 & $\mathrm{U}$ & $X$ & 1 & Minor & $\mathrm{N}$ & $\mathrm{N}$ & $\mathrm{N}$ & $\mathrm{N}$ & $\mathrm{N}$ & $\mathrm{N}$ \\
\hline 55 & $\mathrm{~F}$ & 48 & $\mathrm{U}$ & $X$ & 1 & Minor & $\mathrm{N}$ & $\mathrm{N}$ & $\mathrm{N}$ & $\mathrm{N}$ & $\mathrm{N}$ & $\mathrm{N}$ \\
\hline 56 & $\mathrm{M}$ & 59 & $\mathrm{U}$ & $X$ & 3 & Minor & $\mathrm{N}$ & $\mathrm{N}$ & $\mathrm{N}$ & $\mathrm{N}$ & $\mathrm{N}$ & $\mathrm{N}$ \\
\hline 57 & $\mathrm{~F}$ & 30 & $\mathrm{U}$ & X & 2 & Minor & $\mathrm{Y}$ & $\mathrm{Y}$ & $\mathrm{N}$ & $\mathrm{N}$ & $\mathrm{N}$ & Y \\
\hline 58 & $\mathrm{~F}$ & 72 & U & $X$ & 2 & Minor & $\mathrm{N}$ & $\mathrm{N}$ & $\mathrm{N}$ & $\mathrm{N}$ & $\mathrm{N}$ & $\mathrm{N}$ \\
\hline
\end{tabular}

$\mathrm{U}=$ unknown

${ }^{\mathrm{a}}$ Age at diagnosis.

${ }^{\mathrm{b}}$ Clinical stage at presentation according to the AJCC Cancer Staging Manual criteria (fifth edition); X is unknown stage.

${ }^{\mathrm{c}}$ Histologic grade. ${ }^{14}$

${ }^{\mathrm{d}}$ Origin of tumor in major or minor salivary gland, with parotid, submandibular, sublingual and lacrimal glands considered as major salivary glands and smaller glands of the oropharynx, sinonasal cavities, trachea and larynx considered minor salivary glands. 


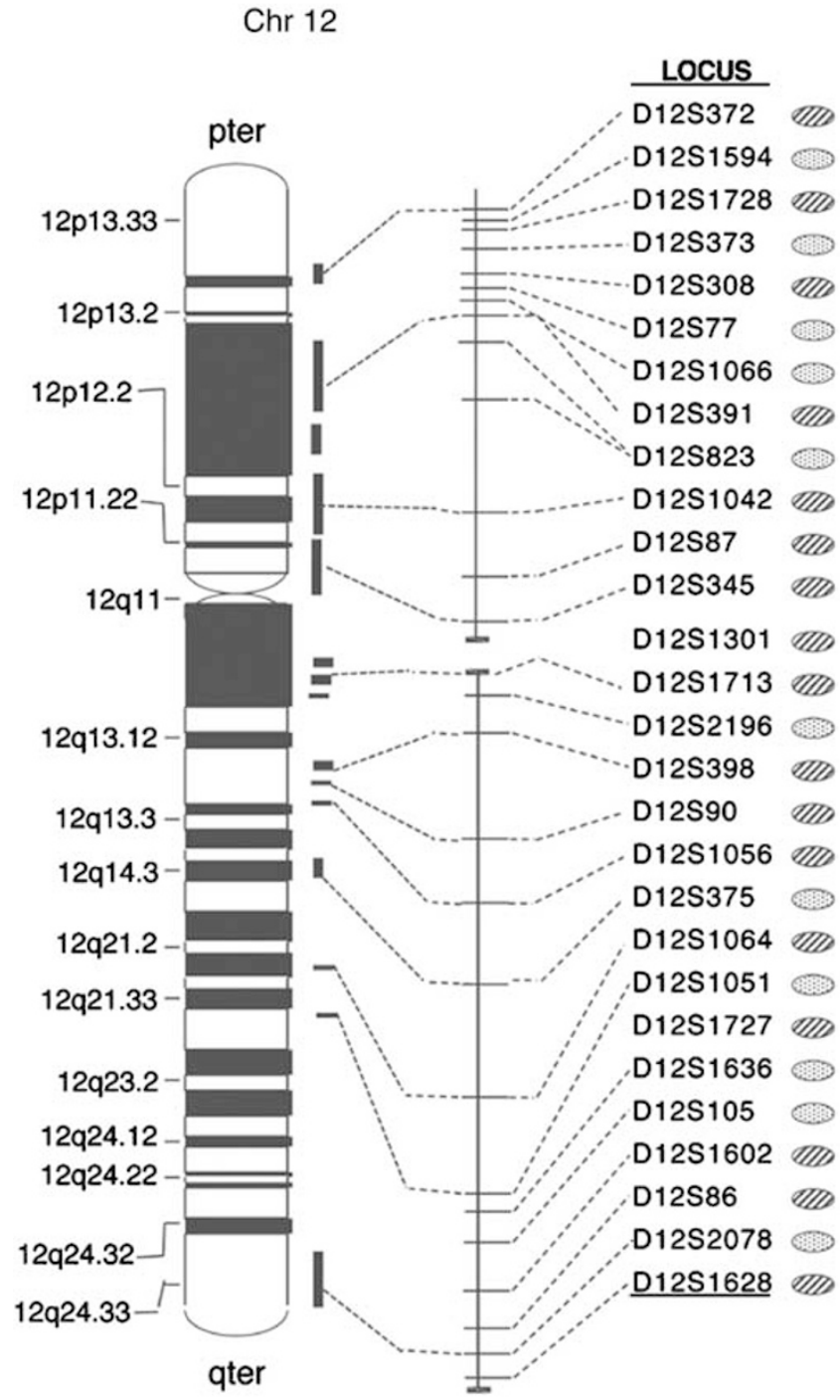

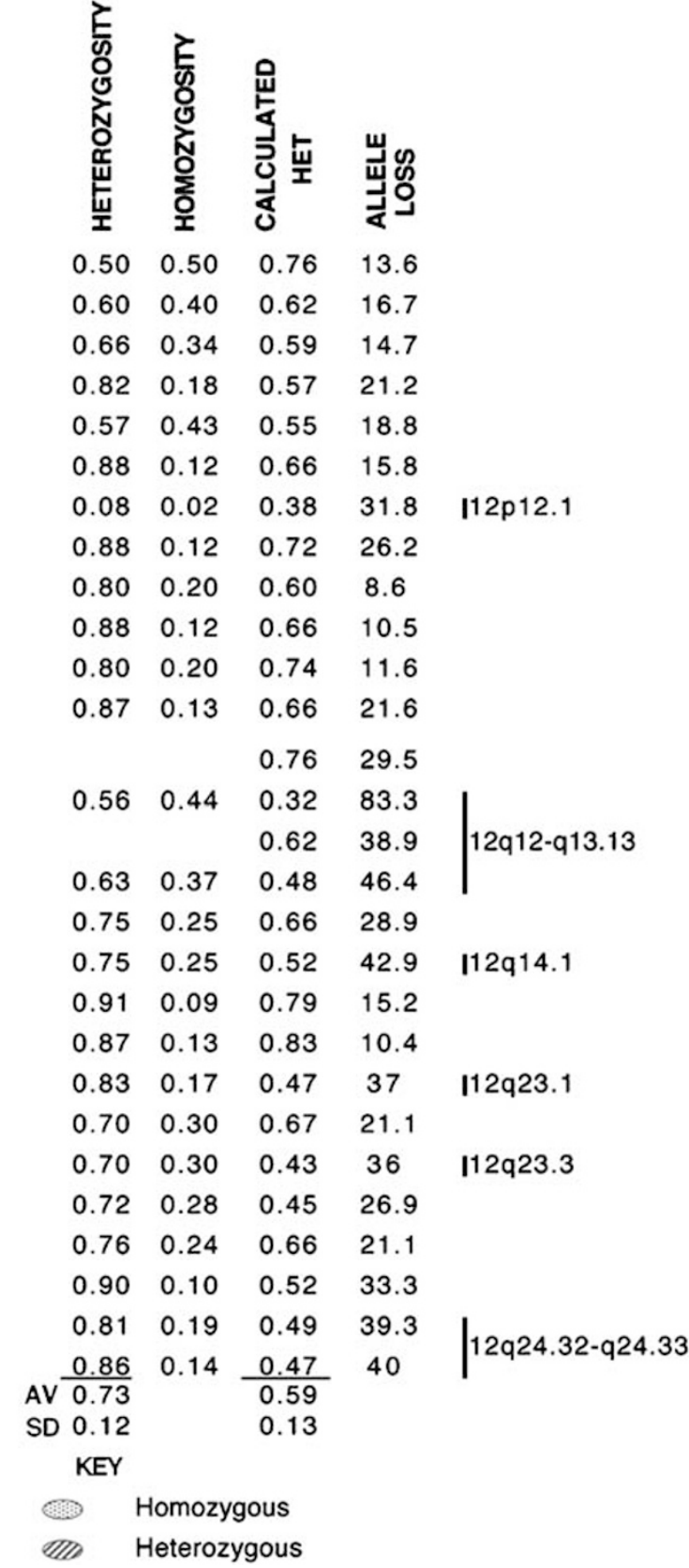

Figure 1 Chromosome 12 microsatellite markers used, their chromosomal location and their genetic distance, where known, are listed on the left, in order from pter (top) to qter (bottom). Genetic distances (Mb) were obtained from the Human Genome Project Working Draft at UCSC, 2003. For each locus, marker heterozygosity for the 28 microsatellite markers are listed on the right and were obtained from either the Genome Database or CEPH family data. The homozygosity values were obtained from the heterozygosity values. Calculated heterozygosity and allele loss was obtained from the LOH analysis in the 58 ACC samples. Results from HOMOD analysis performed on the ACC3 cell line are shown in the oval characters.

\section{Correlation with Survival and Clinicopathologic Parameters}

Kaplan-Meier survival curves were generated using the statistical software package Prism 4.0 (GraphPad Software, Inc.). Survival curves were compared using the log rank test (equivalent to the Mantel-Haenszel test), with two-tailed $P$-values.
Standard errors were calculated by the method of Greenwood, with the 95\% confidence interval computed as 1.96 times the s.e. in each direction. Correlation between $12 \mathrm{q} \mathrm{LOH}$ and other clinicopathologic parameters was performed using the $\chi^{2}$ test for independence in the statistical software package Instat 3.0 (GraphPad Software, Inc.). 


\section{Results}

\section{Microsatellite Loss of Heterozygosity Analysis (LOH)}

In all, 28 microsatellite markers on chromosome 12 markers were selected for $\mathrm{LOH}$ and HOMOD analyses to further characterize the loss of chromosome 12 identified in our previous CGH and LOH study. The markers have an average separation of $4.64 \mathrm{Mb}^{26}$ and an average heterozygosity of 0.78 (Figure 1). Results from $\mathrm{LOH}$ analysis identified overall loss of $66 \%$ (Figure 2) on chromosome 12 with the greatest loss occurring at the D12S1713 marker (LOH rate $=83 \%$ ) (Figures 1 and 2). The D12S1713 marker (LOH rate $=83 \%$ ) located at the chromosome 12q13.11 cytogenetic location also defines one end of a $6.84 \mathrm{Mb}$ region of deletion extending distally to the D12S398 marker (LOH rate $=46 \%$ ) (Figure 1) located at 12q13.13. ${ }^{26}$ The loss identified between the D12S1713 and D12S398 markers also includes the marker D12S2196 (LOH rate $=39 \%$ ) (Figure 1) located at $12 \mathrm{q} 13.11 .{ }^{26}$ Hence, a $6.84 \mathrm{Mb}$ region of deletion is located within the chromosome 12q13.11-q13.13 cytogenetic location (Figures 1 and 2). ${ }^{26}$

Further analysis of the 58 matched ACC and normal samples also identified other localized chromosome $12 \mathrm{q}$ regions of deletion. A $4.5 \mathrm{Mb}$ region defined by the markers $D 12 S 2078$ (LOH rate $=39 \%)$ and $D 12 S 1628(\mathrm{LOH}$ rate $=40 \%)$ located within 12q24.32-q24.33 ${ }^{26}$ shows a significant amount of loss (Figures 1 and 2). The markers, D12S1056 $(\mathrm{LOH}$ rate $=43 \%)$ located at $12 \mathrm{q} 14.1$,
D12S1051 (LOH rate $=37 \%$ ) located at $12 \mathrm{q} 23.1$ and D12S1636 ( $\mathrm{LOH}$ rate $=36 \%$ ) located at $12 \mathrm{q} 23.3^{26}$ also define smaller isolated regions of deletion (Figures 1 and 2). Although not reaching the LOH significance threshold of 35\%, the D12S1066 marker $(\mathrm{LOH}$ rate $=32 \%)$ located at $12 \mathrm{p} 12.1^{26}$ may also indicate a region of deletion involved in the pathogenesis of a subset of ACC.

\section{Database Analysis of Genes in Consensus Deletion Areas}

In an in silico strategy to identify candidate genes, a search of LocusLink ${ }^{27}$ at the National Center for Biotechnology information for loci with the annotated term 'tumor suppressor' yielded 372 loci for the human genome. Of these, five loci coincided with the consensus deletion loci identified in the $\mathrm{LOH}$ analysis of ACC (ANP32D, HCCR1, SP1, DUSP6 and PRDM4). Review of the annotations and scientific literature showed that only one of these candidate genes has the functional or biochemical attributes of a tumor suppressor gene: DUSP6 (dual specificity phosphatase 6/MAP kinase phosphatase 3) at 12q22-q23, a negative regulator of the MAP kinase signal transduction pathway.

\section{Microsatellite Homozygosity Mapping of Deletion (HOMOD)}

Results from HOMOD analysis in the ACC3 cell line shows a maximum of two contiguous homozygous

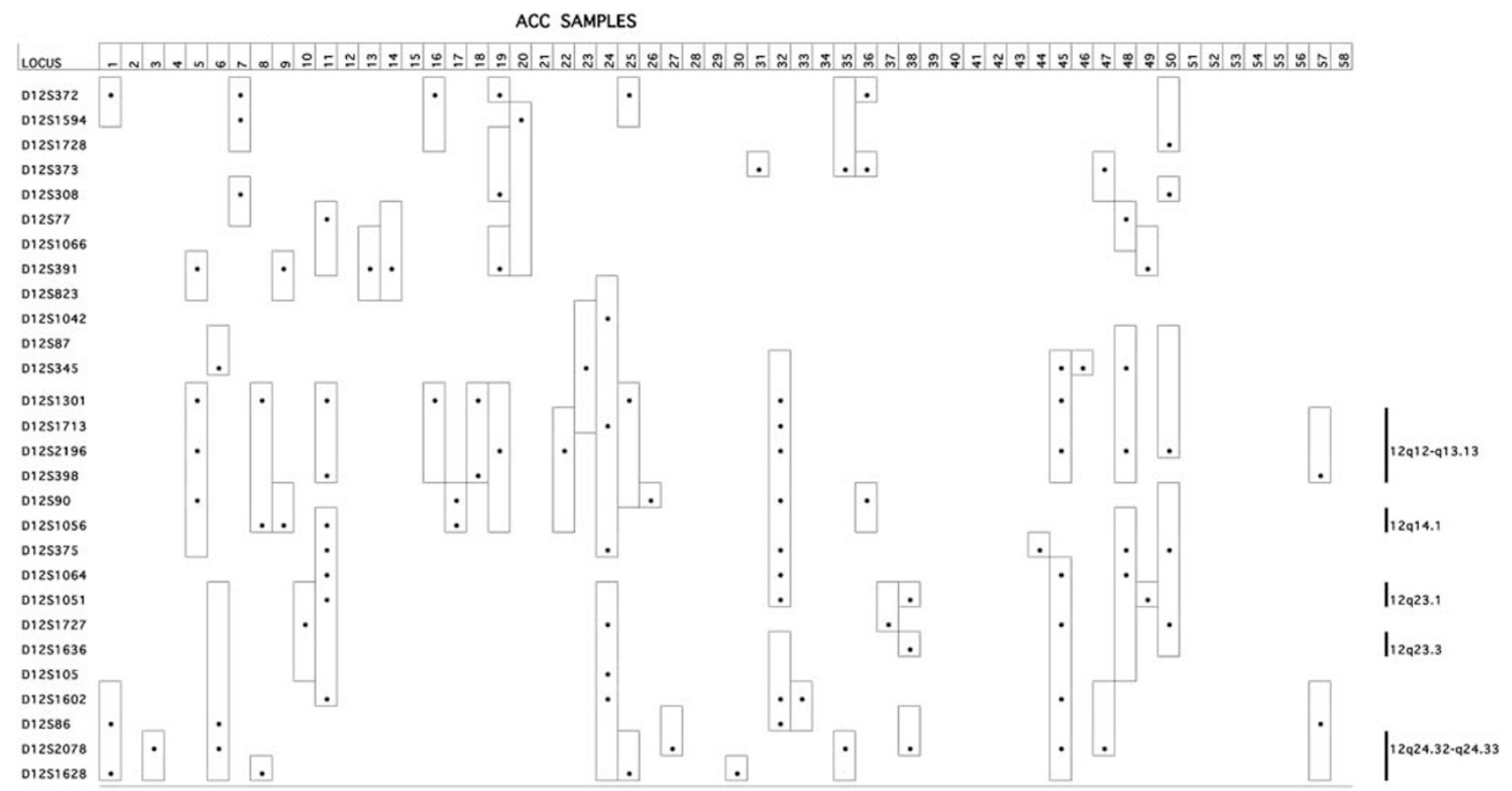

Figure $2 \mathrm{LOH}$ analysis using chromosome 12 markers in 58 ACC. The microsatellite markers used are listed on the left, in order from pter (top) to qter (bottom). The black dots indicate deleted loci. Deletions were found in 38 of 58 cancers (66\%). The major consensus regions of loss are indicated by the black lines to the right of the figure. 
markers in two regions, one defined by the markers, D12S77 and D12S1066 located within the chromosome 12p13.2-p12.1 region and the other defined by the D12S1636 and D12S105 markers located within the chromosome 12q23.3-q24.11 cytogenetic location (Figure 1) ${ }^{26}$ As previously published,${ }^{24}$ regions of loss are defined by the presence of an extended region of homozygosity for five or more adjacent markers which would have a statistical probability of $\leq 0.001$. The two extended regions of homozygosity in the present study were observed for two adjacent markers on chromosome 12 (Figure 1) with the probability of observing this number of homozygous genotypes by chance in non-neoplastic DNA being $0.021(0.1128 \times 0.1852)$ for the $12 \mathrm{p} 13.2-\mathrm{p} 12.1$ and $0.053(0.1852 \times 0.2857)$ for the $12 \mathrm{q} 23.3-\mathrm{q} 24.11$ cytogenetic locations. Hence, these probability values are not less than 0.001 and therefore are not statistically significant.

\section{Correlation of Chromosome Deletion and Gene Expression Profiling Data}

Data obtained from gene expression profiling of 15 ACC and five normal salivary glands on Affymetrix
U95a GeneChips ${ }^{\mathrm{TM}}$ were obtained. ${ }^{19} 209$ probe sets corresponded to the 12q12-q13 locus and 139 probe sets to the 12q24 locus. After filtering for genes that were not significantly expressed in normal salivary gland tissue, 164 and 107 probe sets remained in these loci, respectively. After filtering for genes whose relative expression decreased less than twofold between benign and malignant tissue samples, 29 probe sets, corresponding to 29 unique genes whose expression is significantly decreased in ACC, remained in the 12q12-q13 locus (Table 2). In all, 22 probe sets, corresponded to 17 unique genes, whose expression is significantly decreased in ACC, remained in the 12q24 locus (Table 3).

Although no chromosome 12 deletions were identified in the ACC3 cell line, the gene expression levels of the candidate tumor suppressor genes identified from the analysis of primary tumors showed markedly similar patterns in this cell line. In the 12q12-q13 consensus area, the following genes showed levels similar or lower than the primary tumors: ACVRL1, AQP5, KRT7, SILV, VDR, DDIT3, ERBB3, MGC11308, ACVR1B, RND1, RAPGEF3, HEM1, DHH, MLL2, SOAT2, RBMS2, KRTHB5, FAIM2, NR4A1, MAP3K12. In the 12q24 consensus area, the following genes showed levels

Table 2 List of highest ranked downregulated genes and ESTs within the chr 12q12-q13 region in ACC

\begin{tabular}{|c|c|c|c|c|c|c|}
\hline Affy ID & Symbol & Annotation & $\begin{array}{l}\text { RefSeq } \\
\text { number }\end{array}$ & Unigene ID & $\mathrm{P}$-value* & $\begin{array}{l}\text { Fold } \\
\text { change }\end{array}$ \\
\hline 416_s_at & HOXC5 & Homeo box C5 & NM_018953 & Hs. 820 & $1.32 \mathrm{E}-01$ & 16.4 \\
\hline 1927_s_s_at & ACVRL1 & Activin A receptor type II-like 1 & NM_000020 & Hs.410104 & $2.64 \mathrm{E}-06$ & 8.8 \\
\hline 32909_at & AQP5 & Aquaporin 5 & NM_001651 & Hs.298023 & $5.00 \mathrm{E}-06$ & 5.8 \\
\hline 41293_at & KRT7 & Keratin 7 & NM_005556 & Hs.23881 & $2.13 \mathrm{E}-02$ & 5.3 \\
\hline 38921_at & PDE1B & Phosphodiesterase 1B, calmodulin dependent & NM_000924 & Hs.512605 & 1.79E-01 & 5.0 \\
\hline 38327_at & SILV & Silver (mouse homolog) like & NM_006928 & Hs.95972 & 9.60E-03 & 4.9 \\
\hline 1410_at & VDR & Vitamin D (1,25-dihydroxyvitamin D3) receptor & NM_000376 & Hs.2062 & 3.92E-03 & 4.5 \\
\hline 36266_at & None & Hypothetical protein & None & None & $5.41 \mathrm{E}-03$ & 4.1 \\
\hline 39420_at & DDIT3 & DNA-damage-inducible transcript 3 & NM_004083 & Hs.355867 & 2.97E-03 & 3.5 \\
\hline 1723_g_at & ERBB3 & $\begin{array}{l}\text { v-erb-b2 avian erythroblastic leukemia viral oncogene } \\
\text { homolog } 3\end{array}$ & NM_001982 & Hs.306251 & $9.65 \mathrm{E}-07$ & 3.3 \\
\hline 40935_at & MGC11308 & Hypothetical protein MGC11308 & NM_032889 & Hs.19210 & $1.74 \mathrm{E}-03$ & 3.2 \\
\hline 39199_at & ACVR1B & Homo sapiens mRNA; cDNA DKFZp434M245 & HSM 801180 & Hs.371974 & $5.32 \mathrm{E}-06$ & 3.0 \\
\hline 37785_at & RND1 & GTP-binding protein & & Hs. 124940 & $2.14 \mathrm{E}-02$ & 2.9 \\
\hline 40705_at & RAPGEF3 & $\begin{array}{l}\text { Rap1 guanine-nucleotide-exchange factor directly } \\
\text { activated by cAMP }\end{array}$ & NM_006105 & Hs. 8578 & $1.09 \mathrm{E}-02$ & 2.8 \\
\hline 34415_at & ACVR1B & Activin A receptor, type IB & NM_004302 & Hs.371974 & $1.40 \mathrm{E}-02$ & 2.8 \\
\hline 33639_g_at & ERBB3 & $\begin{array}{l}\text { v-erb-b2 avian erythroblastic leukemia viral oncogene } \\
\text { homolog } 3\end{array}$ & NM_001982 & Hs.306251 & $4.46 \mathrm{E}-03$ & 2.8 \\
\hline 35766_at & KRT18 & Keratin 18 & NM_000224 & Hs.406013 & $7.08 \mathrm{E}-06$ & 2.7 \\
\hline 39201_r_at & None & ESTs & None & None & $5.06 \mathrm{E}-03$ & 2.7 \\
\hline 37953_s_at & ACCN2 & Amiloride-sensitive cation channel 2, neuronal & NM_020039 & Hs. 274361 & $1.57 \mathrm{E}-01$ & 2.5 \\
\hline 37845_at & HEM1 & Hematopoietic protein 1 & NM_005337 & Hs.443845 & $1.46 \mathrm{E}-01$ & 2.5 \\
\hline 485_at & $\mathrm{DHH}$ & $\begin{array}{l}\text { U59748 HSU59748 Human desert hedgehog (hDHH) } \\
\text { mRNA I GenBank = U59748 }\end{array}$ & NM_021044 & Hs.352607 & $1.71 \mathrm{E}-01$ & 2.4 \\
\hline 38165_s_at & MLL2 & Myeloid/lymphoid or mixed-lineage leukemia 2 & NM_003482 & Hs.387381 & 2.08E-02 & 2.4 \\
\hline 32882_at & SOAT2 & Sterol O-acyltransferase 2 & NM_003578 & Hs.20580 & $3.68 \mathrm{E}-03$ & 2.3 \\
\hline 34187_at & RBMS2 & RNA binding motif, single stranded interacting protein 2 & NM_002898 & Hs. 438778 & $1.39 \mathrm{E}-01$ & 2.3 \\
\hline 32328_at & KRTHB5 & Keratin, hair, basic, 5 & NM_002283 & Hs.182507 & $2.96 \mathrm{E}-02$ & 2.2 \\
\hline 33293_at & FAIM2 & Lifeguard & NM_012306 & Hs.182859 & $1.15 \mathrm{E}-04$ & 2.2 \\
\hline 32265_at & NR4A1 & Nuclear receptor subfamily 4 , group A, member 1 & NM_173158 & Hs.1119 & $1.90 \mathrm{E}-02$ & 2.1 \\
\hline 520_at & MAP3K12 & Mitogen-activated protein kinase kinase kinase 12 & NM_006301 & Hs.211601 & 4.63E-02 & 2.0 \\
\hline
\end{tabular}

${ }^{*}$ Calculated by unpaired $t$-test. 
Table 3 List of highest ranked downregulated genes and ESTs within the chromosome 12q24 region in ACC

\begin{tabular}{|c|c|c|c|c|c|c|}
\hline Affy ID & Symbol & Annotation & $\begin{array}{l}\text { RefSeq } \\
\text { number }\end{array}$ & Unigene ID & P-value* & $\begin{array}{l}\text { Fold } \\
\text { change }\end{array}$ \\
\hline 34640_at & TCF-1 & $\begin{array}{l}\text { Transcription factor 1, hepatic; LF-B1, hepatic nuclear } \\
\text { factor (HNF1), albumin proximal factor }\end{array}$ & NM_003202 & Hs.528674 & $2.50 \mathrm{E}-02$ & 29.9 \\
\hline 31707_at & ZNF10 & $\begin{array}{l}\text { X52332:H. sapiens mRNA for zinc-finger protein 10/ } \\
\text { cds }=(70 \mid \text { GenBank = X52332) }\end{array}$ & NM_015394 & Hs.104115 & $2.13 \mathrm{E}-03$ & 9.1 \\
\hline 38388_at & OAS1 & $2^{\prime}, 5^{\prime}$-oligoadenylate synthetase $1(40-46 \mathrm{kD})$ & NM_016816 & Hs.442936 & $1.32 \mathrm{E}-02$ & 9.0 \\
\hline 38332_at & P2RX4 & Purinergic receptor P2X, ligand-gated ion channel, 4 & NM_002560 & Hs.321709 & $2.28 \mathrm{E}-03$ & 6.8 \\
\hline 36972_at & RNP24 & H. sapiens cDNA: FLJ21323 fis, clone COL02374 & NM_006815 & Hs.75914 & 5.07E-07 & 3.2 \\
\hline 41512_at & BRAP & BRCA1-associated protein & NM_006768 & Hs.122764 & 2.97E-02 & 2.9 \\
\hline 39520_at & KIAA0692 & KIAA0692 protein & None & Hs. 524874 & $1.54 \mathrm{E}-03$ & 2.9 \\
\hline 31530_at & ACACB & Acetyl-coenzyme A carboxylase beta & NM_001093 & Hs. 234898 & $1.40 \mathrm{E}-04$ & 2.7 \\
\hline 41646_at & JIK & STE20-like kinase & NM_016281 & Hs. 12040 & 8.96E-05 & 2.7 \\
\hline 653_at & RFC5 & Replication factor C (activator 1) 5 (36.5 kD) & NM_181578 & Hs. 443227 & 2.33E-01 & 2.7 \\
\hline 37815_at & DDX51 & $\begin{array}{l}\text { H. sapiens mRNA full length insert cDNA clone } \\
\text { EUROIMAGE } 152428\end{array}$ & NM_175066 & Hs. 445168 & $5.51 \mathrm{E}-03$ & 2.5 \\
\hline 269_at & OASL & $2^{\prime}-5^{\prime}$-oligoadenylate synthetase like & NM_198213 & Hs. 118633 & 1.19E-02 & 2.5 \\
\hline 36640_at & MYL2 & Myosin, light polypeptide 2, regulatory, cardiac, slow & NM_000432 & Hs.75535 & $1.20 \mathrm{E}-04$ & 2.5 \\
\hline 39264_at & OAS2 & $2^{\prime}-5^{\prime}$-oligoadenylate synthetase $2(69-71 \mathrm{kD})$ & NM_002535 & Hs.414332 & 5.05E-03 & 2.4 \\
\hline 32335_r_at & UBC & Ubiquitin C & None & Hs. 524832 & 7.41E-09 & 2.3 \\
\hline 41507_at & MAPKAPK5 & $\begin{array}{l}\text { Mitogen-activated protein kinase-activated } \\
\text { protein kinase } 5\end{array}$ & NM_003668 & Hs.413901 & 4.49E-02 & 2.1 \\
\hline
\end{tabular}

${ }^{*}$ Calculated by unpaired $t$-test.

similar or lower than the primary tumors: CF-1, ZNF10. P2RX4, RNP24, BRAP, ACACB, JIK, DDX51, OASL, MYL2, OAS2, UBC, MAPKAPK5.

The candidate tumor suppressor gene DUSP6, that is localized to one of the minor consensus deletion areas (12q23.3) showed a 4.5-fold reduction in transcript level in ACC compared to normal salivary gland tissue (average relative fluorescence units for normals 2185, average relative fluorescence units for cancers $483, P=2.1 \times 10^{-6}$ in unpaired $t$-test). In the ACC3 cell line, DUSP6 expression is even lower, with a relative fluorescence unit of 84 .

\section{Correlation of 12q LOH with Survival and Clinicopathologic Data}

To determine if chromosomal deletion of $12 \mathrm{q}$ correlated with patient survival, Kaplan-Meier survival curves were plotted for the parameters of clinical stage, histologic grade and each of the consensus areas of $12 \mathrm{q} \mathrm{LOH}$. When histologic grade was compared, patients with the highest grade cancer (grade III) had significantly worse survival than patients with grade I and II cancers $(P=0.0008$, Figure 3a). When presenting clinical stage was compared, patients with Stage 1 cancers appeared to have a survival benefit compared to all other clinical stages (Figure $3 \mathrm{~b}$ ), but these results did not reach statistical significance. $(P=0.183)$. The results from our cohort are in good agreement with previous literature regarding the effect of histologic grade on prognosis, ${ }^{14,28,29}$ although our data did not show as strong a trend for the effects of clinical stage as previously reported. When the cases with chromosome $12 \mathrm{q}$ loss were compared against each other and against cases with no detectable $12 \mathrm{q} \mathrm{LOH}$, there was no significant difference between groups in longterm survival ( $>100$ months), although this analysis was complicated with the shorter average follow-up time in the group that did not contain deletions (Figure 3c). One deletion area (12q14.1) was associated with increased survival over the rest of the cohort at shorter time intervals. No significant correlation was found between any of the consensus deletion areas and the clinicopathologic parameters of histologic grade and clinical stage.

\section{Discussion}

Previously, we used 24 ACC samples in a CGH and a $\mathrm{LOH}$ assay to allelotype 29 ACC samples with the three chromosome 12 microsatellite markers, D12S391, D12S1301 and D12S1064. ${ }^{12}$ Results from our previous investigation shows a high level of loss on the $\mathrm{p}$ arm of chromosome 12 and the deletion at 12q12-q13 may include a locus telomeric to D12S1301. Results from the current more extensive LOH investigation of chromosome 12 shows $66 \%$ overall loss with most of the loss occurring at the seven chromosome 12q markers, D12S1713, D12S2196, D12S398, D12S1056, D12S1051, D12S1636, D12S2078 and D12S1628 (Figures 1 and 2). Three of these markers, D12S1713, D12S2196 and D12S398 are contiguous and define a $6.84 \mathrm{Mb}$ region of deletion at the chromosome 12q13.11-13.13 cytogenetic location. Hence, these results are consistent with that found in the previous CGH and LOH study showing 12q12-q13 loss. HOMOD analysis of the ACC3 cell line did not detect an area of homozygosity that achieved the 

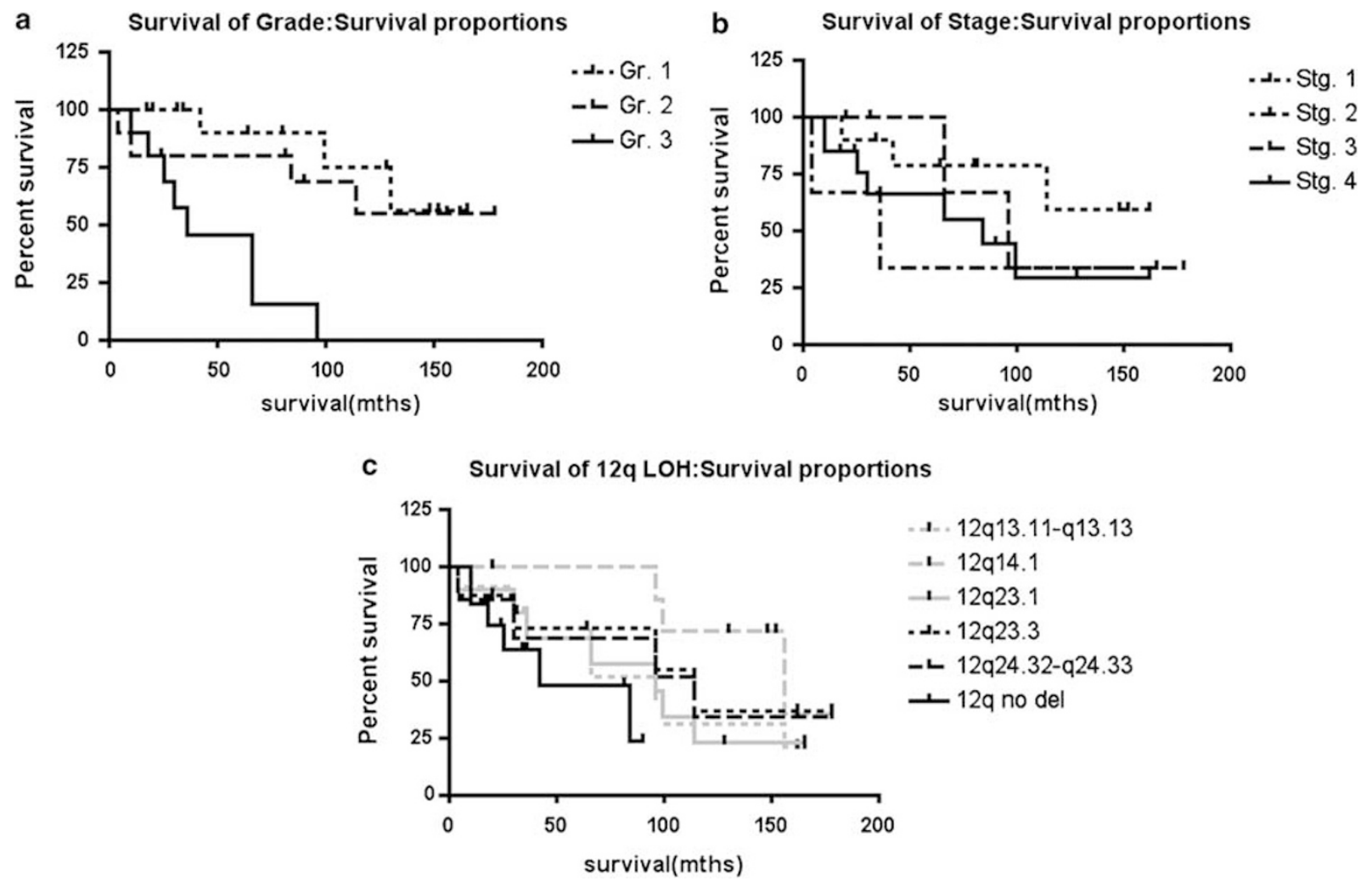

Figure 3 Kaplan-Meier survival curves for cohort subset that has follow-up data. (a) Survival data correlated with histologic grade (grades I-III). (b) Survival data correlated with presenting clinical stage. (c) Survival data correlated with chromosome 12q LOH mapping (Abbreviation 'no del' = no deletion).

statistical significance predictive of genetic deletion. The marker density we employed does not however rule out the possibility that this cell line has 'microdeletions' of less than $4 \mathrm{Mb}$ in size.

Results from the present study also show a $4.5 \mathrm{Mb}$ region of deletion at the 12q24.32-q24.33 defined by the two markers, D12S2078 and D12S1628 (Figures 1 and 2) as well as regions of deletion at 12q14.1 (D12S1056), 12q23.1 (D12S1051) and at 12q23.3 (D12S1636). These regions are less than $5 \mathrm{Mb}$ in size and may be too small for CGH detection. A review of the literature suggests these chromosome 12 losses are rare except in ACC, suggesting a cell-typespecific tumor suppressor effect.

There are several possible mechanisms of tumor suppression. The classic mechanisms entail either homozygous deletion or the combination of deletion of one allele and an inactivating gene mutation in the other allele. A third mechanism entails the deletion of one allele and the loss of gene expression of the remaining allele by promoter silencing. We did not detect an event in our microsatellite PCR analysis suggestive of a homozygous deletion (reproducible lack of amplification of all tumor alleles), leaving the latter two possibilities. Although our $\mathrm{LOH}$ analysis confirms and extends our previous CGH analysis, the consensus areas of deletion overlap remain substantially large, precluding a 'gene by gene' search for tumor-specific mutations.
In a search of genes with tumor suppressor activity annotation, the MAP kinase phosphatase DUSP6 (MKP3/PYST1) was identified in the 12q23.3 deletion locus. Downregulation of DUSP6 protein levels has been shown to occur in invasive pancreatic cancer, and re-expression of DUSP6 in a pancreatic cell line model correlates with reduction of phosphorylated MAP kinase levels and a reduction in cell proliferation. ${ }^{30}$

In searching for candidate tumor suppressor genes potentially inactivated by a combination of genetic deletion and promoter silencing, we combined the data from our current $\mathrm{LOH}$ analysis with microarray gene expression analysis of ACC. A number of genes within 12q12-q13 and 12q24 regions were found to have significantly downregulated expression. These include regulatory genes such as Homeobox C5 (HOXC5) and Activin A Receptor Type II-like I (ACVRL1), and genes more likely to be related to cellular differentiation phenotypes such as Aquaporin 5 (AQP5) and Keratin 7 (KRT7). HOXC5, is a member of the homeobox transcription factors that play an important role in morphogenesis. Interestingly, previous studies of prostate ${ }^{31}$ and cervical cancer $^{32}$ have implicated upregulation of HOXC5 in tumor progression. Our results suggest a different role for HOXC5 in tumor progression of epithelial malignancies in salivary gland tissues. ACVRL1 is a type I cell-surface receptor for the TGF-beta super- 
family of ligands, which has growth-stimulating effects on mesenchymal cells and several tumor cell lines. ${ }^{33}$ The potential loss of such activity makes this gene a strong candidate for further invesigation as a tumor suppressor in ACC. $A Q P 5$ is a water channel protein expressed in submandibular, parotid, sublingual salivary and lacrimal glands. ${ }^{34}$ While the loss of AQP5 in ACC is most likely to represent the loss of a highly differentiated epithelial phenotype during malignant transformation, a recent finding in colon cancer suggests that some ion-regulatory mechanisms may play an etiologic role in molecular tumor progression, ${ }^{35}$ hence a mechanistic role for $A Q P 5$ in ACC cannot be excluded out of hand. Although downregulated, KRT7 continues to be expressed in ACC, ${ }^{36}$ and can be used as part of an immunohistochemical profile to distinguish between ACC and carcinomas of other origins.

The four genes of particular interest within 12q24 are the transcription factor 1 (TCF-1), zinc-finger protein 10 (ZNF10/KOX1), $2^{\prime}, 5^{\prime}$-oligoadenylate synthetase $1(O A S 1)$ and the purinergic receptor P2X (P2RX4), all of which have a 6.8-fold or more reduction in ACC3 expression suggesting there is strong downregulation for these genes in ACC. Previous studies show inactivation of the $T C F-1$ gene is an important genetic event in the occurrence of human liver adenomas and an early step in the development of some hepatocellular carcinomas, with biallelic mutational inactivation. ${ }^{37}$ The zincfinger protein 10 has been shown to function as a transcriptional repressor ${ }^{38}$ while $2^{\prime}, 5^{\prime}$-oligoadenylate synthetase 1 has been implicated in the control of cell growth, differentiation and apoptosis. ${ }^{39}$ Through $\mathrm{Ca}^{2+}$ regulation and other mechanisms, the purinergic receptor appears to regulate salivary cell volume, ion and protein secretion, and increases permeability to small molecules that may be involved in cytotoxicity. ${ }^{40}$

Although no chromosome 12 deletion was detected in the ACC3 cell line using this analysis, the gene expression profiling data for the candidate tumor suppressor genes identified from primary tumors is remarkably similar in this cell line, with the majority of the identified genes showing expression levels at the same or lower magnitude as the primary tumors. These results suggest that this cell line may be used as an appropriate model system to test the effects of these genes on aspects of ACC biology in an experimental setting.

The deletions on chromosome 12 do not appear to be markers of clinical aggressivity in adenoid cystic carcinoma. This is in contrast to reports in the literature of genetic deletions on chromosome 6 , which are correlated with higher clinical stage, higher histologic grade, and poorer clinical outcome. $^{3}$ If these deletions in chromosome 12 do indeed target a specific gene, it may be that the biochemical or regulatory pathway being disrupted is also disrupted in the nondeleted carcinomas by other mechanisms, or that the contribution of these alterations to the biology of ACC are not necessarily reflected in the typical clinical course of the disease.

In conclusion, our finding of a high incidence of chromosome 12 deletion in ACC suggests that these structural genomic changes are consistent with the presence of a tumor suppressor gene (or genes) on this chromosome involved in the pathogenesis of this tumor type. This argument is strengthened by the fact that ACC in general do not show the marked degree of genomic instability found in other carcinoma types, hence the chromosome 12 alterations are less likely to be nonspecific changes associated with the neoplastic phenotype. While the $\mathrm{LOH}$ analysis revealed the presence of relatively large and nonoverlapping consensus areas of deletion, the combination of deletion mapping and transcript microarray analysis has yielded some attractive candidate genes for further functional analysis.

\section{Acknowledgements}

We thank Sharon Birdsall and Mark Clem for assistance in histologic sectioning and Craig Rumpel for microsatellite $\mathrm{LOH}$ analysis and cell culture maintenance of the ACC3 cell line. We also thank Elizabeth Myers and Tyler Cooke for technical assistance. This work was supported by a grant from the National Institute of Dental and Craniofacial Research (RO1-DE-14694) and by a grant from the National Organization for Rare Disorders, Inc. (New Fairfield, CT, USA). The contents of this work are solely the responsibility of the authors and do not necessarily represent the official views of the National Institutes of Health.

\section{References}

1 Johns MM, Westra WH, Califano JA, et al. Allelotype of salivary gland tumors. Cancer Res 1996;56:1151-1154.

2 el-Naggar AK, Hurr K, Kagan J, et al. Genotypic alterations in benign and malignant salivary gland tumors: histogenetic and clinical implications. Am J Surg Pathol 1997;21:691-697.

3 Stallmach I, Zenklusen P, Komminoth P, et al. Loss of heterozygosity at chromosome 6q23-25 correlates with clinical and histologic parameters in salivary gland adenoid cystic carcinoma. Virchows Arch 2002;440: 77-84.

4 Queimado L, Reis A, Fonseca I, et al. A refined localization of two deleted regions in chromosome $6 \mathrm{q}$ associated with salivary gland carcinomas. Oncogene 1998;16:83-88.

5 Kishi M, Nakamura M, Nishimine M, et al. Loss of heterozygosity on chromosome $6 \mathrm{q}$ correlates with decreased thrombospondin-2 expression in human salivary gland carcinomas. Cancer Sci 2003;94: 530-535.

6 Mark HF, Hanna I, Gnepp DR. Cytogenetic analysis of salivary gland type tumors. Oral Surg Oral Med Oral Pathol Oral Radiol Endodcr 1996;82:187-192. 
7 Martins C, Fonseca I, Roque L, et al. Malignant salivary gland neoplasms: a cytogenetic study of 19 cases. Eur J Cancer B Oral Oncol 1996;32B:128-132.

8 Nordkvist A, Mark J, Gustavsson H, et al. Nonrandom chromosome rearrangements in adenoid cystic carcinoma of the salivary glands. Genes Chromosomes Cancer 1994;10:115-121.

9 Cerilli LA, Swartzbaugh JR, Saadut R, et al. Analysis of chromosome 9p21 deletion and p16 gene mutation in salivary gland carcinomas. Hum Pathol 1999;30: 1242-1246.

10 Roijer E, Kas K, Klawitz I, et al. Identification of a yeast artificial chromosome spanning the 8q12 translocation breakpoint in pleomorphic adenomas with t(3;8)(p21;q12). Genes Chromosomes Cancer 1996;17: $166-171$.

11 Ohki K, Kumamoto H, Ichinohasama R, et al. Genetic analysis of DNA microsatellite loci in salivary gland tumours: comparison with immunohistochemical detection of hMSH2 and p53 proteins. Int J Oral Maxillofacial Surg 2001;30:538-544.

12 El-Rifai W, Rutherford S, Knuutila S, et al. Novel DNA copy number losses in chromosome 12q12-q13 in adenoid cystic carcinoma. Neoplasia 2001;3:173-178.

13 Martins C, Fonseca I, Roque L, et al. Cytogenetic similarities between two types of salivary gland carcinomas: adenoid cystic carcinoma and polymorphous low-grade adenocarcinoma. Cancer Genet Cytogenet 2001;128:130-136.

14 Szanto PA, Luna MA, Tortoledo ME, et al. Histologic grading of adenoid cystic carcinoma of the salivary glands. Cancer 1984;54:1062-1069.

15 Rumpel CA, Powell SM, Moskaluk CA. Mapping of genetic deletions on the long arm of chromosome 4 in human esophageal adenocarcinomas. Am J Pathol 1999;154:1329-1334.

16 Cheng J, Irie T, Munakata R, et al. Biosynthesis of basement membrane molecules by salivary adenoid cystic carcinoma cells: an immunofluorescence and confocal microscopic study. Virchows Arch 1995;426: 577-586.

17 He RG, Zhang XS, Zhou XJ, et al. The establishment of cell lines of adenoid cystic carcinoma of human salivary glands (ACC2, ACC3) and a study of morphology. West Chin J Stomatol 1988;6:1-4.

18 Irie T, Cheng J, Kimura S, et al. Intracellular transport of basement membrane-type heparan sulphate proteoglycan in adenoid cystic carcinoma cells of salivary gland origin: an immunoelectron microscopic study. Virchows Arch 1998;433:41-48.

19 Frierson Jr HF, El-Naggar AK, Welsh JB, et al. Large scale molecular analysis identifies genes with altered expression in salivary adenoid cystic carcinoma. Am J Pathol 2002;161:1315-1323.

20 Kimura S, Cheng J, Toyoshima K, et al. Basement membrane heparan sulfate proteoglycan (perlecan) synthesized by ACC3, adenoid cystic carcinoma cells of human salivary gland origin. J Biochem (Tokyo) 1999;125:406-413.

21 Toyoshima K, Kimura S, Cheng J, et al. Highmolecular-weight fibronectin synthesized by adenoid cystic carcinoma cells of salivary gland origin. Japan J Cancer Res 1999;90:308-319.

22 Girard L, Zochbauer-Muller S, Virmani AK, et al. Genome-wide allelotyping of lung cancer identifies new regions of allelic loss, differences between small cell lung cancer and non-small cell lung cancer, and loci clustering. Cancer Res 2000;60:4894-4906.

23 Vogelstein B, Fearon ER, Kern SE, et al. Allelotype of colorectal carcinomas. Science 1989;244:207-211.

24 Goldberg EK, Glendening JM, Karanjawala Z, et al. Localization of multiple melanoma tumor-suppressor genes on chromosome 11 by use of homozygosity mapping-of-deletions analysis. Am J Hum Genet 2000; 67:417-431.

25 NETAFFX Analysis Center. Affymetrix Corporation. Available from http://www.affymetrix.com/analysis/ index.affx

26 Human Genome Project Working Draft. University of California at Santa Cruz. Available from http://genome. ucsc.edu/

27 NCBI Locuslink. Available from http://www.ncbi.nlm. nih.gov/LocusLink/

28 Ellis G, Auclair P. Tumors of the Salivary Glands. 3rd edn. Armed Forces Institute of Pathology: Washington, DC, 1996.

29 Fordice J, Kershaw C, el-Naggar A, et al. Adenoid cystic carcinoma of the head and neck. Predictors of morbidity and mortality. Arch Otolaryngol Head Neck Surg 1999;125:149-152.

30 Furukawa T, Sunamura M, Motoi F, et al. Potential tumor suppressive pathway involving DUSP6/MKP-3 in pancreatic cancer. Am J Pathol 2003;162:1807-1815.

31 Miller GJ, Miller HL, van Bokhoven A, et al. Aberrant HOXC expression accompanies the malignant phenotype in human prostate. Cancer Res 2003;63: 5879-5888.

32 Hung YC, Ueda M, Terai Y, et al. Homeobox gene expression and mutation in cervical carcinoma cells. Cancer Sci 2003;94:437-441.

33 Matsuyama S, Iwadate M, Kondo M, et al. SB-431542 and Gleevec inhibit transforming growth factor-betainduced proliferation of human osteosarcoma cells. Cancer Res 2003;63:7791-7798.

34 Gresz V, Kwon TH, Hurley PT, et al. Identification and localization of aquaporin water channels in human salivary glands. Am J Physiol-Gastrointestinal Liver Physiol 2001;281:G247-G254.

35 Li H, Myeroff L, Smiraglia D, et al. SLC5A8, a sodium transporter, is a tumor suppressor gene silenced by methylation in human colon aberrant crypt foci and cancers. Proc Natl Acad Sci USA 2003;100:8412-8417.

36 Nikitakis NG, Tosios KI, Papanikolaou VS, et al. Immunohistochemical expression of cytokeratins 7 and 20 in malignant salivary gland tumors. Mod Pathol 2004;17:407-415.

37 Bluteau O, Jeannot E, Bioulac-Sage P, et al. Bi-allelic inactivation of TCF1 in hepatic adenomas. Nat Genet 2002;32:312-315.

38 Lorenz P, Koczan D, Thiesen HJ. Transcriptional repression mediated by the $\mathrm{KRAB}$ domain of the human $\mathrm{C} 2 \mathrm{H} 2$ zinc finger protein Kox1/ZNF10 does not require histone deacetylation. Biol Chem 2001; 382:637-644.

39 Castelli J, Wood KA, Youle RJ. The 2-5A system in viral infection and apoptosis. Biomed Pharmacother 1998; 52:386-390.

40 Turner JT, Landon LA, Gibbons SJ, et al. Salivary gland P2 nucleotide receptors. Crit Rev Oral Biol Med 1999;10:210-224. 